\title{
The Effect of Trade Balance on Economic Growth of Somalia (1980 - 2020).
}

\author{
Abdulkhaliq Ahmed Abdulle
}

\begin{abstract}
The prime aim of the study was to investigate the relationship between the trade balance and economic growth in Somalia during the period between 1980 and 2020. The study employed secondary time series data obtained from the World Bank, World Development Indicators (WDI), and African Development Bank. An augmented Dickey-Fuller test (ADF) was adopted in the study to test the stationarity of data variables in the study. The econometric model that was employed in the study was Autoregressive Distributed Lag (ARDL), which aims to find out the short-run and the long-run relationships between the dependent variable (RGDP) and independent variable (trade balance). The study revealed that the trade balance (TB) has a significant negative relationship with the real gross domestic product (RGDP) of Somalia in both Short-run and long run. Furthermore, the unemployment rate has a significant negative relationship with the gross domestic product (GDP) of Somalia in both the short-run and long run. However, foreign direct investment (FDI) and gross domestic product (GDP) have a significant negative relationship in the long run while they have an insignificant relationship in the short-run. The study recommends that the government of Somalia should improve the country's trade balance by increasing production, productivity, and the export.
\end{abstract}

Keywords: Economic growth, Trade balance and ARDL model

\section{Introduction}

The African economy consists of agriculture, trade, industry, and human resources. In 2019, approximately 1.3 billion people were living in 54 countries in Africa (world population data sheet, 2017). The economy of Africa is characterized by economic growth with extreme poverty and considerable disparities between regions and countries (YAO Guimei, 2007). However, Africa is the second-fastest-growing region in the world, experiencing average annual GDP growth of 4.6\% for the period between 2000 and 2016. Recently, from 2017 until 2022, the real GDP growth rate in Africa is estimated to grow at $3.9 \%$ annually (ODI, 2018).

In East Africa, the real GDP of East Africa grew by 5.7 percent in 2018, this is slightly less than the 5.9 percent in 2017 and the highest among African regions. Economic growth is estimated to remain at 5.9 percent in 2019 and 6.1 percent in 2020. Ethiopia, Rwanda, Tanzania, Kenya, and Djibouti have the highest economic growth. The most productive economic sectors in both Ethiopia and Rwanda are industry and service sectors, while in Tanzania and Kenya it is the service sector (African Development Bank Group, 2019).

Nationally, Somalia is now recovering from a prolonged civil war that massively destroyed it both politically and economically. Since 1991, when the central government of Somalia collapsed, Somalia's economy has been working as an informal economy, which is mainly based on livestock, Agriculture, remittance, and telecommunication (Moody's Analytics, 2021).

According to the World Bank (2019), Somalia's GDP was \$917 million in 1991 and $\$ 6.2$ billion in 2018. While in 2005, 2010, and 2012, it was 2.316 billion, 1.071 billion, and 1.306 billion, respectively (United Nations Statistics Division, 2015). However, the annual GDP growth rate of Somalia averaged 1.62 percent 
in the period between 1991 and 2019, with the highest level of 14.88 percent in 1977 and the lowest level of -21 percent in 1994 (trading economics, 2021).

Although Somalia's economy has been recovering in recent years, it is still facing countless Economic and non-economic challenges. For instance, Somalia was affected by several shocks during 2019 and 2020, including droughts, floods, locust invasions, and the covid-19 pandemic. As a result, real GDP, which grew $2.9 \%$ in 2019 , shrank by $1.5 \%$ in 2020 , mainly because of COVID-19 containment measures such as travel restrictions, supply and value chain Disruptions (ADBG, 2021).

The trade balance is considered one of the most important indicators of country's economic growth. A positive trade balance indicates a trade surplus, while a negative trade balance indicates a trade deficit. In Somalia, the trade balance averaged -1048.70 USD million from 1998 until 2019, with the highest level of 101.76 USD Million in 2003 and the lowest level of -3190.50 USD million in 2019 (trading economics, 2019). The above estimated average of Somalia's trade balance shows that Somalia's economy is experiencing a trade deficit. This problem can lead to a decrease in national savings, which can ultimately cause economic loss. Therefore, the main objective of the study was to investigate the relationship between the trade balance and the economic growth of Somalia from 1980 to 2020.

\subsection{Objectives of the study}

a) To investigate the long-run relationship between trade balance and economic growth of Somalia.

b) To investigate the short-run relationship between trade balance and economic growth of Somalia.

\section{Literature Review \\ 2.1 Conceptual Review}

Economic growth and trade balance have been defined variously by different people. Some of these definitions are included: Economic growth is defined as an annual increase in material production expressed in value, during a short period, usually of one year (Mladen. M, 2015). Again, economic growth is defined as the process of increasing the country's real national and per capita income over a long period (NIOS.ac, 2018). Also, economic growth is defined as an increase in the production of economic goods and services, compared to one period of time to another. It can be measured in nominal or real terms (Katrina Kunichiello, 2021). All the above definitions agree that economic growth is an increase in goods and services produced by a country in a period of time. On the other hand, according to Srinibash Dash (2020), trade balance is defined as the difference between a country's monetary value of exports and imports. Also, according to IN FOCUS (2020), trade balance is defined as the numerical difference between a country's export and import of goods and services.

\subsection{Empirical review}

Shoukat Ali et al. (2015) investigated the effect of foreign direct investment (FDI) and trade balance on the economic growth of Pakistan during 1990-2014. By employing the Unit root (ADF) test and the Johansen co-integrated and VECM to test Stationarity, long-run and Short-run relationships of the selected variables respectively. The study found that trade balance has a negative effect on the GDP growth rate of Pakistan.

Deimante Blavasciun el al. (2020) evaluated the impact of the trade balance on the economic growth of European Union Countries. His estimations are based on the panel data over the period of 1998 - 2018, using the OLS Method of multivariate regression analysis with fixed effects and employing two strategies (i) including all trade balance periods, and (ii) adding a deficit dummy variable to evaluate whether during deficit periods we can find a different and significant effect on economic growth. The study shows that the trade balance has a negative and lagging impact on the economic growth of the selected countries.

Wint Thu, A., (2017), studied the relationship between the trade deficit and economic growth in Myanmar through an empirical analysis of the panel data of the period between 1989 and 2015. The researcher employed the Johansen co-integration test and the vector error correction Model respectively to analyze the long-run and short-run relationship between the trade deficit and economic growth in Myanmar. The findings indicated that there is a significant negative relationship between the trade deficit and economic 
growth while in the short -run, there is an insignificant negative relationship between the trade deficit and growth.

Najid Ahmad, et al (2013) studied about the relationship between the Trade deficit and economic growth in Pakistan over the period between 1971 and 2007. GDP is used as a dependent variable while trade deficit and foreign investment as independent variables. Augmented Dickey fuller, Johansen co-integration, and Error correction Model are employed to test Stationarity, long-run and short-run relationship between the dependent and independent variables respectively. However, the findings investigated that, foreign direct investment has a significant and positive relationship with the GDP of Pakistan in the long-run while the trade deficit has negative and insignificant relation with GDP in the long-run. And also found that both variables ate statistically significant and have positive relationships with the GDP of Pakistan in the short run.

Moushumi Dhar (2016), investigated the effect of FDI, Trade Deficit Matter on Gross Domestic Product (GDP) in Bangladesh. A time-series data of the period of 1980 to 2013 is used in this analysis, GDP is adopted as a dependent variable while trade deficit and foreign direct investment as independent variables. The researcher employed Augmented Dickey fuller to check the unit root of the variables, where he tested long-run and relationships of the dependent and independent variables by using Johansen co-integration. The study concluded that foreign direct investment has a significant and positive relationship with GDP of the Bangladesh in the long run while the trade deficit has insignificant relation with GDP in the long run.

\section{Methodology}

\subsection{Research Design and data source}

The study employed a quantitative and ex-post facto research design by obtaining, analyzing, and interpreting data relating to the objectives of the study. The study used annual time series data during the period between 1980 and 2020, which was obtained from the World Bank, African Development Bank Group. An augmented Dickey-Fuller test (ADF), Autoregressive Distributed Lag (ARDL) were used in the study to test the stationarity of the data and to investigate the long-run and short-run relationships of the variables, respectively, by using EViews 9.

\subsection{Model Specification}

In the study, output (y) was considered as the function of Trade balance, Unemployment, and foreign direct investment. The function was written as follows:

$\mathrm{RGDPt}=\mathrm{f}(\mathrm{TB}, \mathrm{UNEMP}, \mathrm{FDI})$

In equation 1, the RGDP denotes Real Gross Domestic Product, TB denotes Trade balance, UNEMP denotes Unemployment rate and FDI represents a foreign direct investment. Equation 1 can be converted into the regression model as follows:

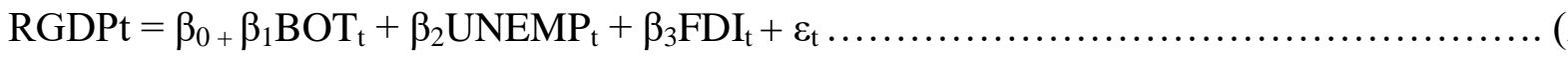

Where RGDP $\mathrm{t}_{\mathrm{t}}$ is the Real Gross Domestic Product, TB is the Balance of Trade, UNMEP is the Unemployment, FDI is the foreign direct investment, et is the Error term (residual), $\beta 0$ is the Constant (intercept) while $\beta 1, \beta 2$, and $\beta 3$ are Parameters to be estimated.

The prime aim of this study is to investigate the long-run and short-run effect of Trade balance on the real gross domestic product (RGDP) of Somalia by using the ARDL model. Therefore, Equation 1 was converted into ARDL long-run and short-run Models, and Equations 3 and 4 were formulated. Equation 3 was the long-run ARDL Mode while equation 4 was the short-run ARDL Model. The equations were written as follows:

$\Delta R G D P t=\beta 0+\beta 1 R G D P t-i+\beta 3 B O T t-i+\beta 3 U N E M P t-i+\beta 4 F D I t-i+\epsilon t$ 
$\Delta R G D P t=\beta 0+\beta 1 \sum_{i=1}^{p} \Delta R G D P t-i+\beta 2 \sum_{j=1}^{q} \Delta B O T t-i+\beta 3 \sum_{k=1}^{q} \Delta U N E M P t-i+$ $\beta 4 \sum_{l=1}^{q} \Delta F D I t-i+\gamma E C t-i+\epsilon t$

In equation 3 and $4, \beta_{1}, \beta_{2}, \beta_{3}$, and $\beta_{4}$ represents coefficients while $\gamma$ represents the coefficient of error correction term.

\section{Empirical Results And Discussion \\ 4.1 Descriptive Analysis}

This Descriptive Analysis aims to analyze the secondary data of this study descriptively and present numerical values of the central tendency and variability of the data by using econometric analysis. The descriptive analysis contains the measures of central tendency which include Mean, mode, and median as well as measures of variation and other statistical characteristics of the variables.

Table 4.1 (Descriptive analysis)

\begin{tabular}{|l|c|c|c|c|}
\hline & RGDP & TB & UNEMPL2 & FDI \\
\hline Mean & 0.547250 & -44.09784 & 12.71400 & 1.723824 \\
\hline Median & 2.600000 & -46.49000 & 13.09500 & 0.105000 \\
\hline Maximum & 10.10000 & 45.72000 & 13.54000 & 9.044000 \\
\hline Minimum & -21.00000 & -91.14000 & 11.21000 & -4.179000 \\
\hline Std. Dev. & 6.128184 & 26.43690 & 0.827841 & 3.623691 \\
\hline Skewness & -1.819103 & 0.716479 & -0.550632 & 0.789759 \\
\hline Kurtosis & 6.368975 & 4.986312 & 1.629234 & 2.468669 \\
\hline & & & & \\
\hline Jarque-Bera & 40.97755 & 9.248159 & 3.864729 & 3.934351 \\
\hline Probability & 0.000000 & 0.009813 & 0.144805 & 0.139851 \\
\hline & & & & \\
\hline Sum & 21.89000 & -1631.620 & 381.4200 & 58.61000 \\
\hline Sum Sq. Dev. & 1464.631 & 25160.75 & 19.87432 & 433.3275 \\
\hline & & & & 40 \\
\hline Observations & 40 & 40 & 40 & \\
\hline
\end{tabular}

Source: Author's Computation using EViews 9

The above table (Table 4.1) presents the following results:

Mean is the average value of the series which is gotten by dividing the total value of the series by the number of observations. From Table 4.1 we see that the mean for GDP, TB, UNEMP, and FDI are $0.547250, \quad-44.09784,12.71400$, and 1.723824 respectively.

Median is the middle value of the series when the values are arranged in an ascending order. From the table (Table 4.1) the median GDP, TB, UNEMP, and FDI are 2.600000, $-46.49000,13.09500$, and 0.105000 respectively.

The maximum and minimum values for RGDP, TB, UNEMP, and FDI are $10.10000 \&-21.00000,45.72000$ $\&-91.14000,13.54000 \& 11.21000,9.044000 \&-4.179000$ respectively.

Standard Deviation is a measure of spread or dispersion in the series. Table 4.1 shows that the standard deviation for RGDP, TB, UNEMP, and FDI are 6.128184, 26.43690, 0.827841 and 3.623691 respectively.

Skewness is a measure of the asymmetry of the distribution of the series around its mean. The skewness of a normal distribution is zero. Positive Skewness implies that the distribution has a long right tail and negative Skewness implies that the distribution has a long-left tail. From the above table (Table 4.1) the skewness value of GDP, TB, UNEMP, and FDI are $-1.819103,0.716479,-0.550632$, and 0.789759 respectively. As a result, GDP, UNEMP have a negative Skewness. This implies that GDP, UNEMP has a long-left tail. Whereas TB and FDI have positive Skewness therefore they have long-right tails. 
Kurtosis measures the peakedness or flatness of the distribution of the series. If the Kurtosis is above three, the distribution is peaked or leptokurtic relative to the normal. But, if the Kurtosis is less than three (3), the distribution is flat or platykurtic relative to normal. Therefore, Table 4.1 reveals that GDP and TB have kurtosis values greater than three, therefore they are peaked or leptokurtic, while UNEMP and FDI have kurtoses values smaller than three, therefore they are flat or platykurtic. 


\subsection{Stationarity Test}

Here, the unit root test (Stationarity test) was tested by using an augmented Dickey-Fuller test (ADF). In this case, a variable can only be Stationary when its ADF statistic is greater than the critical values of 0.05 levels of significance. The results were shown below in table 4.2.

Table 4.2: Unit Root Test for Stationarity At Levels

\begin{tabular}{|c|c|c|c|c|}
\hline VARIABLES & $\begin{array}{c}\text { ADF STAT } \\
\text { @LEVELS }\end{array}$ & $\begin{array}{c}\text { 5\% } \\
\text { CRITICAL } \\
\text { VALUES }\end{array}$ & $\begin{array}{c}\text { ORDER OF } \\
\text { INTEGRATION }\end{array}$ & RESULT \\
\hline RGDP & -3.047030 & -2.963972 & I (I) & STATIONARY \\
\hline TB & -3.822284 & -2.951125 & I (0) & STATIONARY \\
\hline UNEMP & -5.556587 & -2.971853 & I (I) & STATIONARY \\
\hline FDI & -4.122589 & -3.098896 & I (I) & STATIONARY \\
& & & & \\
\hline
\end{tabular}

Source: Author's Computation using EViews 9

The above table (Table 4.2) indicates that TB is stationary at levels, while the GDP, UNMP and FDI are stationary at the first differences. So, since all the variables were stationary at levels and the first differences, the researcher went further to carry out the cointegration test, to check if the selected variables have a long run relationship.

\subsection{Co-integration Test}

ARDL bounds test were used to test if there was a long-run relationship among the dependent and independent variables in the study. In this scenario, a long-run relationship can only be observed when the F-statistic is greater than the upper bounds of the critical value bounds. Results were shown below.

Table 4.3: Testing co-integration test using ARDL bounds.

\begin{tabular}{|l|c|c|}
\hline Test Statistic & Value & $\mathrm{K}$ \\
\hline F-statistic & 15.27762 & 2 \\
\hline Critical Value Bounds & \\
\hline Significance & I0 Bound & $\begin{array}{c}\text { I1 } \\
\text { Boun } \\
\text { d }\end{array}$ \\
\hline $10 \%$ & 3.17 & 4.14 \\
\hline $5 \%$ & 3.79 & 4.85 \\
\hline $2.5 \%$ & 4.41 & 5.52 \\
\hline $1 \%$ & 5.15 & 6.36 \\
\hline
\end{tabular}

Source: Author's Computation using EViews 9

The results in table 4.3 show that the F- statistic is 15.27762 which is greater than the upper bounds of the critical value bounds in the table. Therefore, this result implies that there is a long-run relationship between the dependent variable (RGDP) and independent variables in the study

\subsection{Estimated Long Run Coefficients using ARDL Model}


Table 4.4: Estimated Long Run Coefficients using ARDL Model

\begin{tabular}{|c|c|c|c|c|}
\hline Variable & Coefficient & Std. Error & t-Statistic & Prob. \\
\hline TB & -0.110963 & 0.012549 & -8.842052 & 0.0126 \\
\hline UNEMPL & -0.422464 & 0.079516 & -5.312955 & 0.0336 \\
\hline FDI & -0.761871 & 0.087370 & -8.720052 & 0.0129 \\
\hline C & 5.360774 & 0.891714 & 6.011765 & 0.0266 \\
\hline
\end{tabular}

Source: Author's Computation using EViews 9

From the above analysis in table 4.4, the estimated coefficient of the constant (C) is 5.360774 . This means keeping all the other factors constant, real gross domestic product (RGDP) was increasing by 5.360774 during the period of 1980 and 2020 in the long-run. The estimated coefficient of TB is - 0.110963. This shows that TB and RGDP have a significant negative relationship in the long-run in Somalia. This implies, holding other variables constant, a one percent increase in Trade deficit leads $11.09 \%$ decrease in the RGDP growth rate of Somalia in the long-run. The result confirmed with the studies by Shoukat Ali et al (2015) that, there exists a long-run relationship between trade balance and Economic growth in Pakistan.

The estimated coefficient and P-value of Unemployment are -0.422464 and 0.0336 respectively. This implies that Unemployment has a significant negative effect on the real gross domestic product (RGDP) in the long run. Therefore, this result shows that keeping all other factors constant, a one percent increase in Unemployment leads RGDP to decrease $42.22 \%$ in the long-run.

According to the estimated coefficient and P-value of FDI, the FDI has a significant negative impact on the RGDP growth rate in the long- run in Somalia. This implies a one percent increase in FDI in the long-run results RGDP to decrease in $76.16 \%$ in Somalia.

\subsection{Estimated Short-Run Coefficients using ARDL Model}

Table 4.5: Results of Short-run ARDL Model

\begin{tabular}{|c|c|c|c|c|}
\hline \multicolumn{3}{|c|}{ ARDL $(1,2,2,2)$ selected based on Akaike info criteria } & & \\
\hline Variable & $\begin{array}{c}\text { Coefficien } \\
t\end{array}$ & Std. Error & t-Statistic & Prob. \\
\hline D(TB) & -0.028926 & 0.005162 & -5.603166 & 0.0304 \\
\hline D(UNEMP) & -0.834972 & 0.094165 & -8.867111 & 0.0125 \\
\hline D(FDI) & 0.032393 & 0.072770 & 0.445143 & 0.6998 \\
\hline EC (-1) & -1.267554 & 0.088938 & -14.252166 & 0.0049 \\
\hline $\begin{array}{l}\text { R-squared } \\
\text { Adjusted R-squarec } \\
\text { F-statistic } \\
\text { Prob(F-statistic) } \\
\text { Durbin-Watson sta }\end{array}$ & $\begin{array}{c}0120 \\
0.940720 \\
20.04276 \\
0.048434 \\
3.033632\end{array}$ & & & \\
\hline
\end{tabular}

Source: Author's Computation using EViews 9 
The ARDL Results presented in Table 4.5 above revealed that the coefficient of the lagged error correction term (-1.267554) is negative and statistically significant at 5\% level of confidence. The negative and significant coefficient is indicating the existence of the co-integrating relationship among the model variables. The magnitude of the coefficient implies that about $126.7 \%$ of the disequilibrium caused by the previous year's shocks converges back to the current year's long-run equilibrium.

The estimated coefficient and the P-value of the trade balance are -0.028926 and 0.0304 respectively. This means that there is a negative significant relationship between the Trade balance and the Economic growth rate of Somalia in the short-run. This result implies that a $1 \%$ increase in the trade deficit (TB) leads RGDP to decrease in $2.89 \%$ in the short run. The estimated Coefficient and P-value of Unemployment are 0.834972 and 0.0125 . This result reveals that The Unemployment rate and Economic growth rate of Somalia have a significant negative relationship in the short-run. Furthermore, a $1 \%$ percent increase in unemployment causes the RGDP growth rate of Somalia to decrease in $83.49 \%$ in the short-run.

However, foreign Direct Investment (FDI) has a coefficient of 0.032393 and P - value of 0.6998 , this reveals that there is an insignificant positive relationship between foreign direct investment and real gross domestic product (RGDP) of Somalia in the short-run. The Coefficient of $\left(R^{2}\right)$ is 0.990120 and the adjusted value is 0.940720 indicating that about $99.01 \%$ of total variation or a change in the growth of RGDP is explained by changes in the explanatory variables in the model while the remaining $0.99 \%$ is explained by other factors not included in the study. Additionally, the prob (F- statistic) is 0.048434 which is smaller than 0.05 , this indicates that all the variables jointly in the model Significantly affect the dependent variable at a $5 \%$ significance level.

\section{Conclusion and Recommendations \\ 5.1 Conclusion}

The prime aim of the study was to investigate the relationship between the trade balance and economic growth in Somalia during the period between 1980 and 2020. The study employed secondary time series data obtained from the World Bank, World Development Indicators (WDI), and African Development Bank through internet. An augmented Dickey-Fuller test (ADF) was adopted in the study to test the stationarity of data variables in the study. Additionally, the Econometric model that was employed in the study was Autoregressive Distributed Lag (ARDL) which aims to find out the short-run and long-run relationships between the dependent variable (RGDP) and independent variable (Trade balance). The study revealed that the trade balance (TB) has a significant negative relationship with the real gross domestic product (RGDP) of Somalia in both the short-run and long run. Furthermore, the Unemployment rate had a significant negative relationship with the gross domestic product (GDP) of Somalia in both the short-run and long-run. However, foreign direct investment (FDI) and gross domestic product (GDP) have a significant negative relationship in the long-run, while they have an insignificant positive relationship in the short-run.

\subsection{Recommendations}

According to the above results, the study suggests the following recommendations to the government of Somalia, especially the Ministry of Planning and every sector concerned by this study:

1. The study found that the trade balance had been a significant negative effect on the economic growth rate of Somalia in both the short-run and long-run during last four decades. Therefore, the government of Somalia should come up with effective policies to reduce the trade deficit in the country. These policies against trade deficit include: improving the productivity of endowment factors; inflation stabilization; export encouragement; and making effective trade and monetary policies.

2. The unemployment rate has a significant negative effect on the real gross domestic product (RGDP) of Somalia. Unemployment increases poverty, increases income inequality, wastes resources, social problems and others. All these factors promoted by unemployment can adversely affect Somalia's economic stability. Therefore, the government of Somalia should minimize the level of unemployment rate by educating and giving skills and training to Somali youth to reduce the structural unemployment rate. Also, the government can reduce the unemployment rate by applying a cutting tax policy, which can improve the spending power of citizens and increase aggregate demand and ultimately lead to economic growth. 
3. The Study found that FDI negatively relates to the gross domestic product (GDP) in long-run. while in the short-run it has a positive relation to the GDP. The study suggests that the government should follow up on foreign direct investments in Somalia and how they are managed, in order to get effective and sustainable solutions to the economic problems.

\section{References}

1. The World Bank (2017). World Population Data sheet. https://en.wikipedia.org/wiki/Economy_of_Africa\#cite_note-worldbank.org-3

2. YAO, G. (2007). The Main Trends and Characteristics of African Economic Development. https://www.ide.go.jp/library/Japanese/Publish/Reports/Kidou/pdf/2007_03_03_1_yao_e.pdf.

3. Overseas Development Institute (ODI), (2018). African's economic growth in a new global context. https://odi.org/en/events/africas-economic-growth-in-a-new-global-context.

4. African development Bank Group (2019). East Africa Economic Outlook 2019, Macroeconomic developments and prospects. The African Development Bank group. https://www.afdb.org/fileadmin/uploads/afdb/Documents/Publications/2019AEO/REO_2019__East_Africa_.pdf.

5. Moody's Analytics, (2021). Somalia - Economic Indicators, https://www.economy.com/somalia/indicators.

6. World Banka, (2019). Data of Somalia, Data.worldbank.org. https://en.wikipedia.org/wiki/Economy_of_Somalia\#cite_note-21.

7. UNSD, (2015). United Nations Statistics Division in Somalia. https://en.wikipedia.org/wiki/Economy_of_Somalia\#cite_note-21.

8. African Development Bank Group, (2021). Somalia Economic outlook. https://www.afdb.org/en/countries-east-africa-somalia/somalia-economic-outlook.

9. Trading economics, (2021). Somalia Balance of Trade 2021 Data | 2022 Forecast | 1998-2020 Historical. https://tradingeconomics.com/somalia/balance-of-trade.

10. Mladen. M, (2015). Economic growth and development. Journal of process management (JPMNT) - new technologies, international, vol.3, No.1,2015.

11. IN FOCUS, (2020). The U.S. Trade Deficit: An Overview. Congressional Research Service. https://crsreports.congress.gov/.

12. Katrina, K. (2021). Macroeconomics- economic growth definitions. Investopedia. https://www.investopedia.com/terms/e/economicgrowth.as.

13. Srinibash, D. (2020). Dynamic relationship between Trade Balance and Macroeconomics

Variables in India. TEST Engineering and Management. Volume 83, page 401.

14. Shoukat Ali, Anam Naz and Rana Muhammad, (2015), impact of FDI and Trade balance on economic growth during 1990-2014, a case study of Pakistan. Historical Research Letter, Vol.25, 25. https://www.researchgate.net/publication/283349933.

15. Deimante, B., Lina, G., \& Kristina, M., (2020). Trade balance effects on economic growth:

Evidence from European Union Countries. Economies 2020, 8, 54.

https://doi.org/10.3390/economies8030054.

16. Wint Thu, A. (2017). Relationship between trade deficit and Economic growth: Empirical analysis of Myanmar. KDI school of Public Policy and Management. page: 27. https://core.ac.uk/download/pdf/213855462.pdf.

17. Najid, A., Umair, A., Muhammad, F., and Muhammad L. (2013). Relationship Between Trade Deficit and Economic Growth in Pakistan: An Econometric Investigation. Australian Journal of Basic and Applied Sciences, 7(7), 963. http://www.ajbasweb.com/old/ajbas/2013/may/963967.pdf.

18. Moushumi Dhar, (2016). Do FDI, Trade Deficit Matter for Gross Domestic Product in Bangladesh? An Economic Investigation. Journal of Economics and sustainable development. Vol 7, No 24 (2016). https://www.iiste.org/Journals/index.php/JEDS/issue/view/2783.

19. Macrotrends LLC (2010-2021). Somalia Foreign Direct Investment 1970-2021. https://www.macrotrends.net/countries/SOM/somalia/foreign-direct-investment. 
Historical Research Letter

www.iiste.org

ISSN 2224-3178 (Paper) ISSN 2225-0964 (Online)

Vol.25, 2

Impact of FDI and Trade Balance on Economic Growth during 1990-2014, a Case Study of Pakistan

Impact of FDI and Trade Balance on Economic Growth during 1990-2014, a Case Study of Pakistan

Impact of FDI and Trade Balance on Economic Growth during 1990-2014, a Case Study of Pakistan

Impact of FDI and Trade Balance on Economic Growth during 1990-2014, a Case Study of Pakis

Impact of FDI and Trade Balance on Economic Growth during 1990-2014, a Case Study 